fishmeal (FM) (121 kg FM and $74 \mathrm{~kg}$ barley grain/t), whereas in the goat trial, FM mixture (FG) was composed $(\mathrm{kg} / \mathrm{t})$ of 769 barley grain, $112 \mathrm{SBM}, 50 \mathrm{FM}$, the other ingredients remaining the same as in the control mixture. CP (g/kg DM) content was 201, 194 and 199 for C, FE and FG mixtures, respectively. DM and CP degradation of the 3 concentrate mixtures were measured using nylon bags incubated in the rumen $(2,6,16,24$ and $32 \mathrm{~h})$ of 3 Damascus goats. There were no significant differences between mixtures for $\mathrm{DM}$ or $\mathrm{CP}$ effective (degradability values at various incubation periods combined mathematically with outflow rates $(5 \% / \mathrm{h})$ of small particles from the rumen) degradability values (C : DM 51.7, CP 45.0 ; FM : DM 50.8, CP 38.3, FG : DM 53.1, CP $46.4 \%)$.

Milk yield of ewes fed fish meal (FE) was significantly $(\mathrm{P}<0.05)$ higher than that of those fed the $\mathrm{C}$ diet (FE 3.84 vs C $3.44 \mathrm{~kg} /$ day). There were no difference between treatments in ewe milk fat (C 44 vs FE $43 \mathrm{~g} / \mathrm{kg}$ ) or protein content (C 54 vs FE $53 \mathrm{~g} / \mathrm{kg}$ ), whereas milk yield of goats was similar in the two treatments (C 3.87 vs FG $3.82 \mathrm{~kg} /$ day). However goats fed FM produced milk with a higher fat (C 32 vs FG $36 \mathrm{~g} / \mathrm{kg}$ ) and protein (C 38 vs FG $41 \mathrm{~g} / \mathrm{kg}$ ) content. Except a better conversion (milk/gain ratio) efficiency (C 5.17 vs FE 4.44) of male lambs of suckling ewes fed the fish meal diet, no other difference on the performances of lambs or kids was observed. Lambs consumed less milk than kids (Lambs: males 4.69 , females 5.13 ; kids : males 6.63 , females 6.98 ) per unit of bodyweight gain.

In another trial, different levels $(0,0.3,0.6$ or $0.9 \mathrm{~g} \mathrm{HCHO} / 100 \mathrm{~g} \mathrm{SBM})$ of $40 \%$ formaldehyde were used for treating SBM. Treated SBM was stored in sealed polyethylene bags for 1 or 5 days. Bags were then opened and treated SBM was laid onto a plastic sheet forming layers of $2.5 \mathrm{~cm}$ depth and left exposed for $72 \mathrm{~h}$. Treated and untreated SBM were incubated into the rumen of 3 Damascus goats for 8 and $24 \mathrm{~h}$ for determination of dry matter (DM) and crude protein (CP) disappearance (D). Increasing levels of HCHO reduced DM and CP D. Mean DM and $\mathrm{CP}$ disappearance of the two incubation periods was : control : 50.0, 32.2, 0.3 HCHO : 41.0, $14.5,0.6 \mathrm{HCHO}: 37.0,10.7 ; 0.9 \mathrm{HCHO}: 33.0,10.4 \%$. Storage period did not affect D, but both $D M$ and $C P$ were increased with prolonged incubation periods $(8 \mathrm{~h}: 34.5 ; 13.0 ; 24 \mathrm{~h}$ : $45.5 ; 21.6 \%)$.

Key words: Ewes, goats, protein source, formaldehyde treatment, milk yield.

\title{
Nitrogen flows in the gut of dairy goats: quantitative and qualitative aspects
}

\author{
F. LAURENT, G. BLANCHART, J. BRUN-BELLUT
}

E.N.S.A.I.A.-INRA, Sciences Animales, 2, avenue de la Forêt de Haye, 54500 Vandouvre (France)

Nitrogen flows were measured in the gut of two lactating goats $(2 \mathrm{~kg}$ milk per day) fitted with a simple rumen and a duodenal cannulas and housed in metabolic crates. They were fed ad libitum in two equal meals during 30 days for each diet. The diets consisted of green roughage (raygrass $=$ RGA) and concentrates or maize silage $(M)$ or a mixed diet (hay, dried beet pulps, concentrates $=$ HPC). The OM, CP and CF contents (\% DM) were 83.9, 92.8, 94.9 and 14.0, 12.0, 7.8 and 30.3, 24.5, 22.7 respectively for RGA, HPC and M diets. PDIN and PDIE values were 104 and 105,52 and 83,107 and $115 \mathrm{~g} / \mathrm{kg}$ DM respectively for RGA, M and HPC diets. Digesta flows were estimated on the $21^{\text {th }}$ day using PEG $(30 \mathrm{~g} /$ day $)$ and chromic oxyde $(2 \mathrm{~g} /$ day $)$ as markers. Microbial fraction was calculated after determining RNA level in duodenal digesta and NRNA/totalN ratio of bacteria isolated by differential centrifugation of duodenal content.

The amount of ingested dry matter was 1777,1538 , and $771 \mathrm{~g}$ respectively for HPC, RGA and $M$ diets. With HPC and RGA diets the amounts of ingested nitrogen ( 34.9 and $39.1 \mathrm{~g} /$ day) was higher than the nitrogen entering the duodenum (22 and $30 \mathrm{~g} / \mathrm{day})$. Net nitrogen recycling into the rumen seemed to be very important $(+15 \mathrm{~g} /$ day $)$ with $\mathbf{M}$ diet.

Microbial nitrogen/NAN ratio in the duodenum varied between $50 \%(\mathrm{M}), 68 \%(\mathrm{HPC})$ and $80 \%$ (RGA). The mean flow of NRNA $(2.4,2.3$, and $1.6 \mathrm{~g} /$ day) for HPC, RGA and $M$ was 1.8 fold higher than the ingested amount showing net synthesis of RNA in the rumen. Microbial efficiency synthesis ( $\mathrm{g}$ microbial $\mathrm{CP} / \mathrm{kg}$ DOM) varied between 109 for HPC, 159 for M, and 161 
for RGA. Apparent NRNA digestibility in the intestine (73, 85 and $83 \%$ for HPC, RGA, and M) was higher than total $\mathrm{N}$ digestibility $(50$ to $81 \%$ ) : this pointed out the very high degradability of RNA in the intestine. The mean flow of digested NRNA represented $9 \%$ of the amount of total digested nitrogen.

A total of 25 to 50 and $86 \%$ of total digested nitrogen (for diets M, HPC, RGA respectively) was excreted in urine. Urinary nitrogen allantoïn represented between $35 \%$ (HPC) and $58 \%$ for RGA $(47 \%$ for $M)$ of the amount of digested NRNA and 4 to $12 \%$ of total urinary nitrogen. Purine nitrogen valorization could then be estimated between 42 to $65 \%$. This value seemed to be higher for lactating goats than for sheep or billy goats at maintenance.

All these results show that the dairy goat can utilize as well NRNA as total nitrogen coming out at the duodenal level.

Key words: Nitrogen flow, nitrogen metabolism, goat.

\title{
Feed intake, digestibility and nitrogen retention in lactating dairy goats fed increments of urea and fish meal
}

\author{
J.E. LINDBERG, P. CISZUK \\ Swedish University of Agricultural Sciences, Department of Animal Nutrition and Management, \\ Kungsängens gård, S-755 90 Uppsala (Sweden)
}

Balance measurements were made in dairy goats of the Swedish Landrace breed. A total of 14 goats with an average live weight of $49 \mathrm{~kg}$ were used during the 3 experimental years.

Experimental diets were composed of $400 \mathrm{~g} \cdot \mathrm{kg}^{-1}$ hay and $600 \mathrm{~g} \cdot \mathrm{kg}^{-1}$ concentrate mixture on feed basis. The concentrate mixtures were not supplemented or supplemented with increasing amounts of urea $(0.9,1.8,2.7$ and $3.5 \%)$ and fish meal $(3.9,7.9,11.7$ and $15.8 \%)$.

A standard diet $\left(344 \mathrm{~g} \cdot \mathrm{kg}^{-1}\right.$ hay and $656 \mathrm{~g} \cdot \mathrm{kg}^{-1}$ concentrate mixture $)$ was fed after parturition and between experimental periods as a reference diet to establish the production capacity of each goat. The standard concentrate was composed of barley, oats, molasses-beet pulp, wheat bran and soyabean meal.

All diets were fed ad libitum. Collections were made for two weeks after an adaptation period of at least three weeks to experimental diets and two weeks to the standard diet. Buffer-soluble crude protein was analysed with a mineral buffer adjusted to $\mathrm{pH}$ 6.7-6.9 and rumen degradability of crude protein was determined with nylon bags with $20 \mu \mathrm{m}$ pore size.

There was a gradual increase in buffer-soluble crude protein (BSCP) and rumen degradable crude protein (EPD) in concentrates with added urea. The opposite was true in concentrates with added fish meal. EPD and BSCP in concentrate mixtures were linearly $(P<0.001)$ related $\left(r^{2}=0.72\right)$.

The average feed intake was $86.4 \mathrm{~g} / \mathrm{kg} \mathrm{P} 0.75(\mathrm{SD}=4.7)$. Feed intake showed large between animal variation, mostly marked at low and at high crude protein content in the diet. The relative feed intake (in $\%$ of intake on the standard diet) decreased significantly $(P<0.01)$ with increasing urea and fish meal supplementation. However, milk protein production was well maintained on the fish meal diets.

Organic matter digestibility was similar on all diets $(73 \%, \mathrm{SD}=0.7)$. Crude fibre (CF) digestibility varied between diets, but was significantly $(P<0.001)$ related to the amount of BSCP in feed organic matter in unsupplemented and fish meal supplemented diets. Significant $(P<0.05)$ individual differences in CF digestibility were also noticed.

The nitrogen balances (total $\mathrm{N}$ retention - milk $\mathrm{N}$ ) were not significantly influenced by the diets fed and was on average $1.9 \mathrm{~g} \mathrm{~N}$ per day $(\mathrm{SD}=0.6)$. The milk $\mathrm{N}$ output was on average $12.4 \mathrm{~g} / \mathrm{d}(\mathrm{SD}=1.5)$ on the experimental diets. Increasing supplementation of urea, above the 